\title{
Nonporous Refractory Coatings Permit Use of Mild Steel for High Temperature Applications
}

D URING the war a method of upgrading mild steel was used with success for the protection of the mild steel exhaust pipes fitted to the engines of British Spitfire and Mosquito aircraft. Since the war, the process has been improved, according to British Engineering, July 1951.

The latest finish, shown as Stoneclad, was developed by Matthews Refractories, Ltd., London, S. W. 17, and is applied by Stewart \& Gray, Ltd. It is designed to protect mild steel or cast iron from corrosion at high temperatures and to permit their use in many instances where heat-resisting steel otherwise would be specified. An exception is where the high temperature is accompanied by considerable stress. It consists in carrying, in a boro-silicate matrix, a suspension of insoluble refractories and bonding it to the metal surface by fusion at about $1472^{\circ} \mathrm{F}$. The treatment may be a single homogeneous coat $0.004 \mathrm{in}$. thick where resistance to oxidation only is required; or it may be in two coats, the upper being more refractory than the lower, porous, and $0.020 \mathrm{in}$. to $0.060 \mathrm{in}$. thick. The properties of the coating depend upon the proportions of refractory to matrix, the particle size, the number of layers present, and the porosity of the upper face. It is always nonporous at the metal interface.

The process has been applied successfully to the emitting surface of radiant heaters used for space and industrial heating. In an industrial heater in which a mild steel sheet is heated by products of combustion from a bar burner at the bottom of the combustion chamber formed between the steel sheet and a slab of insulating material, a baffle plate is fitted behind the radiating surface. This shields the lower part from overheating due to direct exposure to the products of combustion and radiation from the flames and insulating slab. The panel temperature of this heater originally was limited to $650^{\circ} \mathrm{F}$ because, at that temperature, the baffle plate was at about $932^{\circ} \mathrm{F}$, above which it is not advisable to heat mild steel for long periods if scaling is to be avoided.

The radiant panels and baffle plates of these appliances are now protected by the Stoneclad proc- ess. The finish of the panels is smooth and black or dark gray in color, its purpose being to prevent rusting; while the baffle plates have a comparatively rough surface brought about by the inclusion of a higher proportion of refractory material. This results in a greater resistance to high temperatures and thermal shock.

The heater with the panel and baffle plate protected by this process has operated for $5000 \mathrm{hr}$ at a panel temperature of approximately $850^{\circ} \mathrm{F}$ at which the baffle plate is about at $1148^{\circ} \mathrm{F}$. On occasions, however, the panel temperature has been as high as $890^{\circ} \mathrm{F}$ and the baffle temperature $1274^{\circ} \mathrm{F}$. The high panel temperature attained in these tests was the result of doubling the normal heat input of the appliance while the panel was radiating on to the surroundings at approximately room temperature.

The tests on the unprotected baffle plate were concluded at $1700 \mathrm{hr}$ because the scaling of the mild steel was having an adverse effect on the performance of the appliance, and the material had failed. In contrast, there was no appreciable change in the appearance of the protected baffle plate after heating for $1700 \mathrm{hr}$ and after $5000 \mathrm{hr}$ heating. It was still working satisfactorily after $7000 \mathrm{hr}$ under the same conditions.

Apart from this application it is used on a number of space heating appliances. A finish similar to that used for the protection of baffle plates has been applied with success to a fabricated mild steel mixing chamber, used in connection with some experiments in which products of combustion at about $1472^{\circ} \mathrm{F}$ passed through a central tube while comparatively cool recirculated gases were fed into the annulus surrounding the tube before being mixed with the hot gases. Unprotected mild steel had a life of only a few hours, whereas the upgraded mild steel appeared to be in its original condition at the end of the experiments.

The smooth finish as applied to the panels of radiant heaters is claimed to be suitable for use up to a temperature of $1238^{\circ} \mathrm{F}$ and the refractory finish for baffle plates for temperatures up to $1472^{\circ} \mathrm{F}$. 